K. NONAKA, ${ }^{1,2}$ E. KONDRATSKAYA, ${ }^{1,4}$ M. MAEDA, ${ }^{1,3}$ T. YAMAGA, ${ }^{1}$

N. MURAYAMA, ${ }^{2}$ M. -C. SHIN, ${ }^{1}$ and N. AKAIKE ${ }^{1}$

\title{
MODULATION OF GLYCINERGIC TRANSMISSION IN THE RAT SPINAL DORSAL COMMISSURAL NUCLEUS BY GINKGOLIDE B
}

\author{
Received 01.08.09
}

The action of ginkgolide B (GB), the powerful compound of Ginkgo biloba extract, on glycinemediated spontaneous currents in rat spinal sacral dorsal commissural nucleus (SDCN) neurons was examined. IPSCs evoked in spinal cord slices were inhibited in a dose-dependent manner by the addition of GB to the superfusion solution. The amplitude of eIPSCs was reduced to $61 \pm 6.4 \%$ by $10 \mu \mathrm{M} \mathrm{GB}$, with acceleration of the kinetics of the currents indicating the effect of GB on channel pores. Both the amplitude and success ratio $\left(\mathrm{R}_{\text {suc }}\right)$ of eIPSC induced by electrical focal stimulation of single glycinergic nerve endings (boutons) also decreased in the presence of $1 \mu \mathrm{M}$ GB. These data suggest that GB modulates not only post-synaptic glycine receptors but also the pre-synaptic glycine release machinery.

Keywords: spinal glycine receptor, evoked inhibitory postsynaptic current (eIPSC), presynaptic bouton, focal stimulation, ginkgolide $B$.

\section{INTRODUCTION}

Glycine and $\gamma$-aminobutyric acid (GABA) are considered to assemble fast synaptic inhibitory transmission within neuronal networks in the CNS [1]. The primary impact of glycine on the control of both motor and sensory pathways has been confirmed to be mediated throughout the brainstem and spinal cord [2]. A pharmacological influence of glycinergic inhibition by a glycine transporter produced a profound antiallodynia effect in a peripheral nerve partial ligation model in mice [3], whereas disinhibitory mechanisms may contribute to abnormal pain occurring after peripheral nerve injury [4]. Therefore, ligands for both GABA and glycine receptors have important implications in relative disease states and nociception, since these agents can potentially be used to relieve the pain $[5,6]$, whereas antagonists cause neuronal excitation. Such antagonists are often used to discriminate between receptor subtypes with respect to their brain region and/or cellular localization.

\footnotetext{
${ }^{1}$ Kumamoto Health Science University, Kumamoto, Japan.

${ }^{2}$ Graduate School of Science and Technology, Kumamoto University, Kumamoto, Japan.

${ }^{3}$ Kurume University, Kurume, Japan.

${ }^{4}$ Bogomolets Institute of Physiology, National Academy of Sciences of Ukraine, Kyiv, Ukraine.

Correspondence should be addressed to E. Kondratskaya

(e-mail: elena_kondratskaya@yahoo.com).
}

Remarkably, the functional alliance between the above-mentioned inhibitory transmitter systems has been proved for the intraspinal circuitry. The respective statements include the synaptic colocalization of special receptors, the existence of functional transporters, and co-release of both active substances due to input stimulation [7]. Therefore, the development of selective pharmacological tools is a promising outline to control glycinergic transmission and modulate the neuronal excitability, especially in the spinal cord, since the latter was reported to serve as an intermediary "relay" formation for pain processing and suppression mechanisms, where the role of glycine receptors is beyond doubts.

Strychnine-sensitive glycine receptors share the topology, transmembrane arrangement, and pentameric subunit assembly with members of the ligand-gated ion channel receptor superfamily [8]. The general similarities of receptor structure might predict the common influence of both glycine and GABA receptor types by the rank of modulators, as has been found for picrotoxin and strychnine [9].

A terpenic trilactone, ginkgolide $B(\mathrm{~GB})$, the powerful constituent from Ginkgo biloba extract demonstrated previously to be a platelet-activity factor (PAF) antagonist [10], is a blocker of glycinegated channels with a somewhat higher potency for $\beta$ subunit-composed receptors, in particular $\alpha 2 \beta$ hetero- 
oligomers [11]. The efficacy of GB as an open-channel blocker was mainly investigated in hippocampal and cortex glycine receptors [12], i.e., in the brain regions never evidenced to compose pure glycinergic synapses, where glycine receptors are rarely expressed. The impact of inhibitory glycinergic transmission in these structures, if at all, seems to be a minor to GABAergic.

In the current study, we investigated the action of GB on glycine-mediated currents in spinal neurons of the rat sacral dorsal commissural nucleus (SDCN). Neurons from the SDCN are known to receive glycinergic, GABA-ergic, and mixed synaptic inputs [13, 14] and are implicated in pain perception $[15,16]$. In an attempt to clarify the physiological relevance for GB as a channel blocker due to diverse "vivid" conditions for signal driving, we have examined the effect of GB on spontaneous and evoked inhibitory postsynaptic currents (sIPSCs and eIPSCs, respectively) both in spinal cord slices and in acutely isolated neurons with functional synaptic boutons remaining $[13,17]$. Thus, we have compared here the effects of GB on sIPSCs in slices and single neurons, as well as on electrically induced eIPSCs in slices and with a focal single-bouton stimulation technique, i.e., in the situations reflecting the action of ginkgolides on glycine receptors within different transmission modes.

\section{METHODSs}

Surgical procedures. All experiments were performed in accordance with the Guiding Principles for Care and Use of Animals in the Field of Physiological Sciences of the Physiological Society of Japan and approved by the local Animal Experiment Committee in the Kumamoto Health Science University (Japan). Wistar rats (10-12 days old) were decapitated under pentobarbital anesthesia $(50 \mathrm{mg} / \mathrm{kg}$, i.p.). A segment of the lumbosacral (L5-S4) spinal cord was dissected and transversely sliced in ice-cold artificial cerebrospinal fluid at a thickness of 350-370 $\mu \mathrm{m}$ using a microslicer (VT1000S; Leica, Germany). Slices were kept in an incubation medium at room temperature $\left(25^{\circ} \mathrm{C}\right)$. The incubation medium consisted of $(\mathrm{mM}): \mathrm{NaCl}$, 124; $\mathrm{KCl}, 5 ; \mathrm{KH}_{2} \mathrm{PO}_{4}, 1.2 ; \mathrm{NaHCO}_{3}, 24 ; \mathrm{CaCl}_{2}, 2.4$; $\mathrm{MgSO}_{4} \cdot 7 \mathrm{H}_{2} \mathrm{O}, 1.3$; and glucose 10 ; the saline was saturated with $95 \% \mathrm{O}_{2}$ and $5 \% \mathrm{CO}_{2}(\mathrm{pH} 7.4)$.

Slice preparation and isolation of neurons. Slices were transferred to a recording chamber (volume $300 \mu \mathrm{l}$ ) that was continuously perfused with a normal external solution $(\mathrm{mM}): \mathrm{NaCl}, 119 ; \mathrm{KCl}, 2.5 ; \mathrm{CaCl}_{2}$, 2.5; $\mathrm{MgSO}_{4} \cdot 7 \mathrm{H}_{2} \mathrm{O}, 1.3 ; \mathrm{NaH}_{2} \mathrm{PO}_{4}, 1 ; \mathrm{NaHCO}_{3}, 26.2$; and glucose, 11 , equilibrated with $95 \% \mathrm{O}_{2}+5 \% \mathrm{CO}_{2}$ and delivered with a gravity-fed perfusion system at a flow rate of $2-3 \mathrm{ml} / \mathrm{min}$. Neurons of the SDCN (Fig. 1A) were visually identified with an infrareddifferential interference contrast (IR-DIC) video microscope (Leica DM SDK; IR-1000 (DAGEMTI, USA) and captured with CoolSNAP ES2 (CCD ICX285). The patch pipette solution for the wholecell patch recording in slice preparations consisted of (mM): Cs methanesulfonate, 145; TEA-Cl, 5; CsCl, 5; EGTA, 2, HEPES, 10 (pH 7.2). For suppression of the postsynaptic $\mathrm{GABA}_{\mathrm{A}}$ responses, most experiments were performed in an internal solution without ATP, where the $\mathrm{GABA}_{\mathrm{A}}$ response was eliminated by superfusion with an ATP-free internal solution [21, 22].

For mechanical dissociation, slices were transferred into a culture dish (Primaria 3801; Becton Dickinson, USA). The region of the SDCN (Fig. 1A) was identified under a binocular microscope. The details of mechanical dissociation have previously been described [23, 24]. Single SDCN neurons were acutely dissociated from slices using a manufactured vibrating cell-isolating setup (S-I L cell Isolator; KT Labo, Japan). Then, SDCN neurons were identified under microscopic visual control. The external solution used for dissociated neurons consisted of $(\mathrm{mM}): \mathrm{NaCl}, 150 ; \mathrm{KCl}, 5$; $\mathrm{CaCl}_{2}, 2 ; \mathrm{MgCl}_{2}, 1$; glucose 10, and HEPES 10; $\mathrm{pH}$ was adjusted to 7.4 with Tris-OH. The composition of a pipette-filling solution for single-cell experiments was as follows (mM): CsF, 135; TEA-Cl, 5; $\mathrm{CsCl}, 5$; EGTA, 2 and HEPES, 10, but without ATP; pH of the solution was adjusted to 7.2 with Tris-OH.

Electrophysiological recordings. All electrical measurements were performed using the conventional whole-cell patch recording mode at a holding potential $\left(V_{\mathrm{H}}\right)$ of $0 \mathrm{mV}$ using a patch-clamp amplifier (CEZ2300; Nihon Kohden, Japan). Patch electrodes were fabricated from borosilicate glass capillaries of a $1.5 \mathrm{~mm}$ outer diameter (Model GD-1.5, Narishige Scientific Instruments Lab, Japan) with a programmable puller (P-97; Sutter Instruments, USA). The tip resistance of the electrodes filled with the solution was 6-8 M $\Omega$ for slice preparations and 4-5 $\mathrm{M} \Omega$ for dissociated neurons. Current and voltage values were continuously monitored on an oscilloscope and a pen recorder. The membrane currents were filtered at $1 \mathrm{kHz}(\mathrm{E}-3201 \mathrm{~A}$ Decade Filter; NF Electronic Instruments, Japan), digitized at $4 \cdot 10^{-3} \mathrm{sec}^{-1}$, and stored on a computer equipped with pCLAMP 8.02 (Axon Instruments, 
USA). To monitor the access resistance, $10 \mathrm{mV}$ hyperpolarizing step pulses $(30 \mathrm{msec}$ long $)$ were periodically delivered.

The SDCN neurons receive glutamatergic, glycinergic, GABA-ergic, and mixed synaptic inputs. To isolate pharmacologically glycine-mediated events from GABA-ergic ones, an ATP-free internal solution and $3 \mu \mathrm{M}$ bicuculline were used. In addition, to suppress the possible activation of glutamate receptors, $5 \mu \mathrm{M}$ NBQX and $5 \mu \mathrm{M}$ D-AP5 were routinely added to the external solution. The SDCN region in slices was visualized using video-enhanced infrared microscopy, and individual SDCN neurons were chosen for recording due to their morphology. Spontaneous sIPSCs and evoked ones (eIPSCs) were recorded in a whole-cell recording mode at a $V_{\mathrm{H}}$ of $0 \mathrm{mV}$ under voltage-clamp conditions. In order to achieve eIPSCs from SDCN neurons, the stimulation electrode was positioned near the central canal region. Short negative pulses (5-10 $\mu \mathrm{A}, 100 \mu \mathrm{sec}$ long) were applied through a glass pipette filled with the standard external solution via a stimulus isolation unit.

Synaptic bouton preparation. Both sIPSCs and eIPSCs were recorded from synaptic bouton preparations. In recordings of eIPSCs at single glycinergic synapses, the electrical focal stimulation pipette was placed close to the surface of a dissociated SDCN neuron, from which whole-cell recording was made. Then, negative pulses $(100 \mu$ sec long $)$ were delivered every 3 or $5 \mathrm{sec}$. The stimulating pipette having about a $0.5 \mu \mathrm{m}$ diameter was filled with the standard external solution and moved along the surface of the somatic membrane and proximal dendrites until an eIPSC was elicited in an "all-or-none" fashion, indicating that the stimulating pipette (electrode) was positioned just above the bouton. The current appeared in an "all or none" fashion when the stimulus strength was increased or when the stimulation pipette was moved. The current was highly sensitive to $0.3 \mu \mathrm{M}$ tetrodotoxin (TTX) [23]. The success ratio $\left(\mathrm{R}_{\text {suc }}\right)$ was measured as a ratio of the number of eIPSC $_{\mathrm{s}}$ ' the number of focal stimulations with or without GB. For example, 24 eIPSC $_{\mathrm{s}} / 30$ focal stimulations gives $\mathrm{R}_{\text {suc }}=0.8$. The eIPCSs appeared like in an "all or none" fashion, but the amplitude histogram of eIPSCs recorded in the normal external solution with $2 \mathrm{mM}$ $\mathrm{Ca}^{2+}$ could be fitted by Poisson process.

Data analysis. Glycinergic IPSCs were counted and analyzed in preset epochs before, during, and after each test condition using the MiniAnalysis Program (Synaptosoft, USA). Briefly, the events were initially screened automatically using an amplitude threshold of $10 \mathrm{pA}$ and then visually accepted or rejected based on their 10 to $90 \%$ rise and 90 to $37 \%$ decay times. The interevent intervals and amplitudes of sIPSCs were examined by constructing and comparing cumulative probability distributions under different conditions using the Kolmogorov-Smirnov (K-S) test (Stat View software, SAS Institute, USA). The average values of both frequency and amplitude of synaptic events during the control period (3-5 min) were calculated, and the frequency and amplitude of all events in the course of drug application were normalized to these values. The effects of drugs were quantified as percentage changes in the frequency and amplitude of synaptic events and compared with the individual control. Possible differences between the amplitude and frequency distributions were tested by Student's paired two-tailed t-test using their absolute values. On the other hand, the interevent intervals and amplitudes of a large number of synaptic events obtained from the same neuron were examined by constructing cumulative probability distributions and compared using the $\mathrm{K}-\mathrm{S}$ test within the MiniAnalysis Program.

The current amplitude of eIPSCs was analyzed using pCLAMP 8.0. Numerical values are reported as means \pm \pm s.e.m. A possible significance of the differences in the amplitude was tested by Student's paired twotailed $t$-test using the absolute values of the parameter (not normalized ones). The differences with $P<0.05$ were considered to be significant.

Drugs exposure. The following drugs were used in this study: TTX, bicuculline methiobromide, strychnine, and GB (Sigma, USA). All drugs were stored frozen $\left(-20^{\circ} \mathrm{C}\right)$ as concentrated stock solutions and dissolved in the extracellular solution to the appropriate concentration just before recording. All test solutions containing drugs were applied by a standard gravity bath perfusion system at a flow rate of 2 to $3 \mathrm{ml} / \mathrm{min}$ for slice preparations and by a "Ytube system" for rapid solution exchange within $20 \mathrm{msec}$ in experiments on dissociated neurons [25].

\section{RESULTS}

First, we examined the effect of GB on sIPSCs recorded in spinal cord slices. Bath application of $1.0 \mu \mathrm{M}$ GB exerted negligible effects on the sIPSC amplitude and frequency (data not illustrated). At a higher GB concentration $(10 \mu \mathrm{M})$, strong inhibition was observed, with the mean IPSC amplitude decreasing 


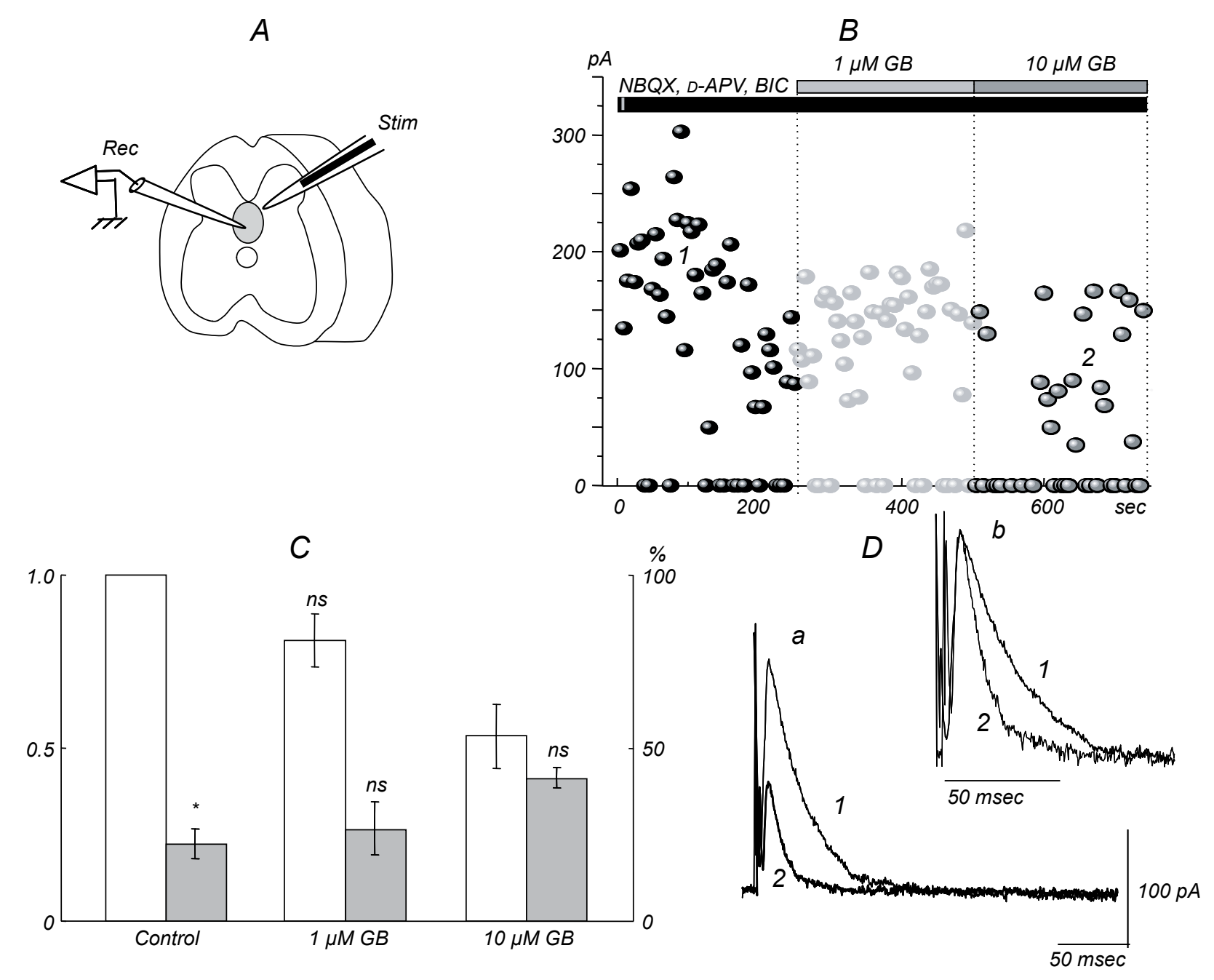

Fig. 1. Effects of ginkgolide B (GB) on glycinergic evoked inhibitory postsynaptic currents (eIPSCs) recorded from neurons of the sacral dorsal commissural nucleus (SDCN) in rat spinal cord slices.

A) Schematic illustration of the SDCN region (shown by an ellipse on the cord section) and positions of recording (Rec) and stimulation (Stim) electrodes. B) Amplitudes of representative recordings of eIPSCs (pA) before and during application of GB (1 and $10 \mu \mathrm{M})$ shown by dashed bars above the diagram. C) Summary of the GB effect on the normalized amplitude and success ratio ( $\left.\mathrm{R}_{\text {suc }}\right)(\%)$ of eIPSCs; $n=5$, $* P<0.05$ C. D) Original traces of eIPSCs recorded before and during application of $10 \mu \mathrm{M} \mathrm{GB}$, and currents normalized by peak before and after GB application (1 and 2, respectively).

Р и с. 1. Вплив гінкголіду Б (GB) на викликані гліцинергічні гальмівні постсинаптичні струми, зареєстровані в нейронах сакрального дорсального комісурального ядра у зрізах спинного мозку щура.

to $61 \pm 6.4 \%$, while the frequency decreased to $78 \pm$ $\pm 9 \%(n=4)$.

The amplitude of eIPSCs was randomly distributed varying between 50 and $350 \mathrm{pA}$. When $1.0 \mu \mathrm{M}$ GB dissolved in the standard extracellular solution was applied, a slight decrease in the eIPSC amplitude was observed without affecting the $\mathrm{R}_{\text {suc }}$ (Fig. 1B, C). However, application of GB at a higher concentration $(10 \mu \mathrm{M})$ significantly decreased the eIPSC amplitude $(n=4, P<0.05)$ and also decreased slightly the $\mathrm{R}_{\text {suc }}$
$(P>0.05)$, as shown in Fig. $1 \mathrm{~B}, \mathrm{C}$. Moreover, 10 $\mu \mathrm{M}$ GB profoundly changed the inactivation kinetics of evoked glycinergic currents being indicative of a channel mode of the inhibitory action, as reported by Kondratskaya et al. (2004). In the responses shown in Fig. 1D, the half-decay time was $33 \mathrm{msec}$ for the control and changed to $20 \mathrm{msec}$ in the presence of $10 \mu \mathrm{M}$ GB.

Spontaneous IPSCs were also observed in dissociated SDCN neurons (synaptic bouton preparations) at the 
A

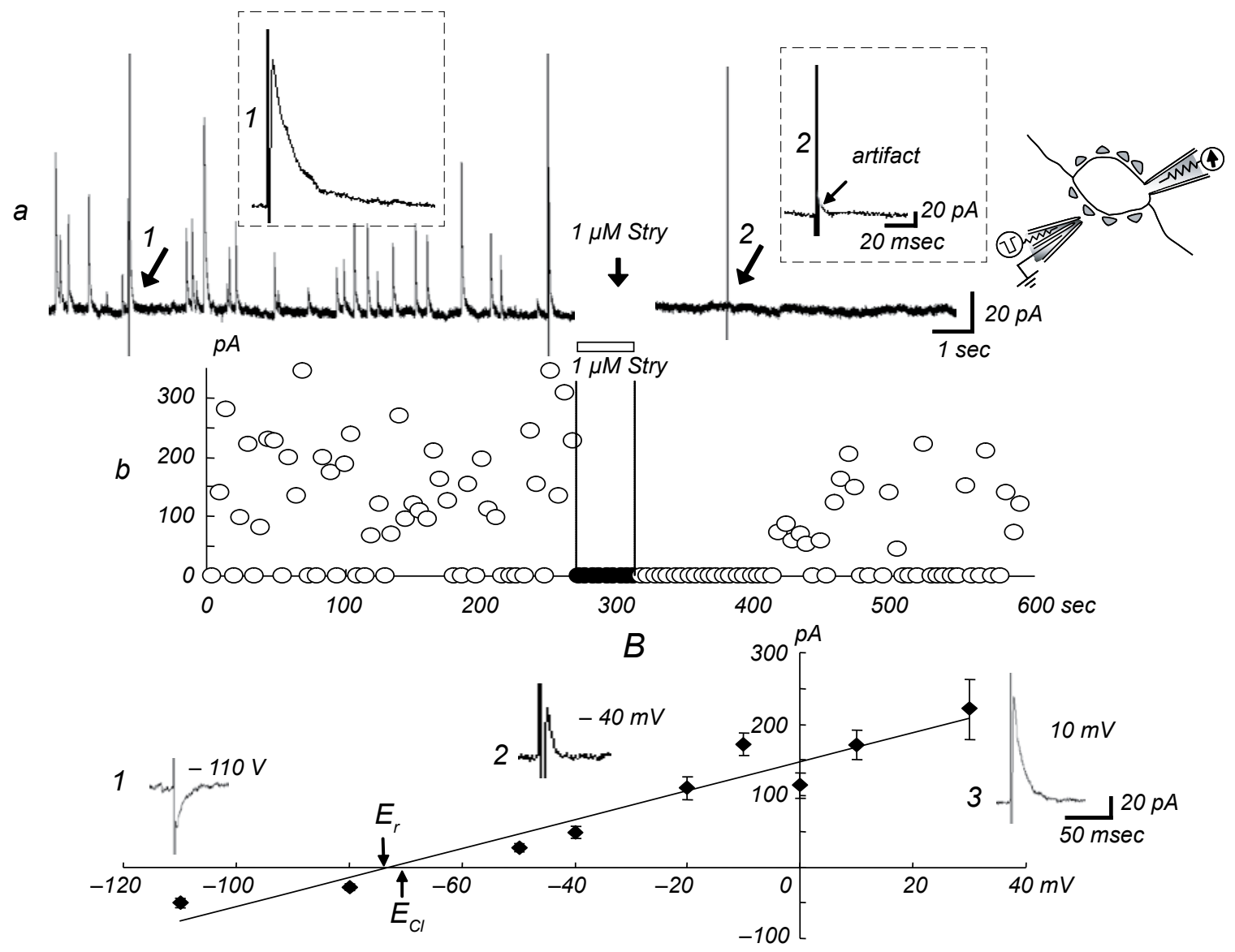

Fig. 2. Glycinergic eIPSCs and sIPSCs observed in dissociated SDCN neurons (in a synaptic bouton preparation).

In A: panel a) Typical IPSCs evoked by focal stimulation (eIPSPs) of a single glycinergic bouton before and after application of $1 \mu \mathrm{M}$ strychinine, Stry (shown by downward arrow). Many spontaneous IPSPs (sIPSPs) were recorded simultaneously from the same neuron. Focal stimulation was given at every $5 \mathrm{sec}$. Arrow 1 shows an eIPSP before Stry application; arrow 2 shows the absence of an eIPSP upon Stry application (the respective fragments 1 and 2 in dotted frames are presented at an expanded sweep scale). Inset at the right) Schematic illustration of a "synaptic bouton" preparation with positions of recording and stimulation electrodes. Panel b is analogous to panel B in Fig. 1; application of Stry reversibly inhibits both eIPSCs and sIPSCs. B) Current-voltage (I-V) relationship for eIPSCs induced by focal stimulation of a single glycinergic bouton. The mean amplitudes (I, pA) are plotted $v s$ the holding potential $V$ (V, mV). Insets $1-3$ show typical eIPSCs at different $V_{\mathrm{H}}$ values. The reversion potential $\mathrm{E}_{\mathrm{r}}$ and chloride equilibrium potential $\mathrm{E}_{\mathrm{Cl}}$ are indicated.

Р и с. 2. Гліцинергічні викликані та спонтанні гальмівні постсинаптичні струми в дисоційованих нейронах сакрального дорсального комісурального ядра (препарат синаптичного з'єднання).

holding potential $\left(V_{\mathrm{H}}\right)$ of $0 \mathrm{mV}$ in a whole-cell patch recording configuration (Fig. 2A). In the experiments, contamination by glutamatergic sEPSCs and GABAergic sIPSCs was removed pharmacologically. All sIPSCs could be completely inhibited by a competitive glycine receptor antagonist, strychnine (1 $\mu \mathrm{M})$, indicating that the recorded sIPSCs are mediated by strychinine-sensitive glycine receptors. Both the amplitude and frequency of sIPSCs were decreased by GB $(1 \mu \mathrm{M})$, suggesting that dissociated preparations are more sensitive than slice ones (Fig. 2A, 2, right panel).
Glycinergic eIPSCs evoked by electrical focal simulation of single glycinergic boutons using "synaptic bouton" preparations are also shown in Fig. 2A [13, 17]. Strychinine $(1 \mu \mathrm{M})$ reversibly inhibited these eIPSCs even if the current strength of focal stimulation was increased. By recording eIPSCs at the $V$ between $+30 \mathrm{mV}$ and $-110 \mathrm{mV}$, the mean reversal potential estimated from the corresponding I-V relationship was $-73.1 \mathrm{mV}(n=4$, Fig. 2B). This value was close to the $E_{\mathrm{Cl}}(-69.9 \mathrm{mV})$ calculated from the Nernst equation using the $\left[\mathrm{Cl}^{-}\right]_{i}=10 \mathrm{mM}$ and $\left[\mathrm{Cl}^{-}\right]_{\mathrm{o}}=161 \mathrm{mM}$ values for internal and external 


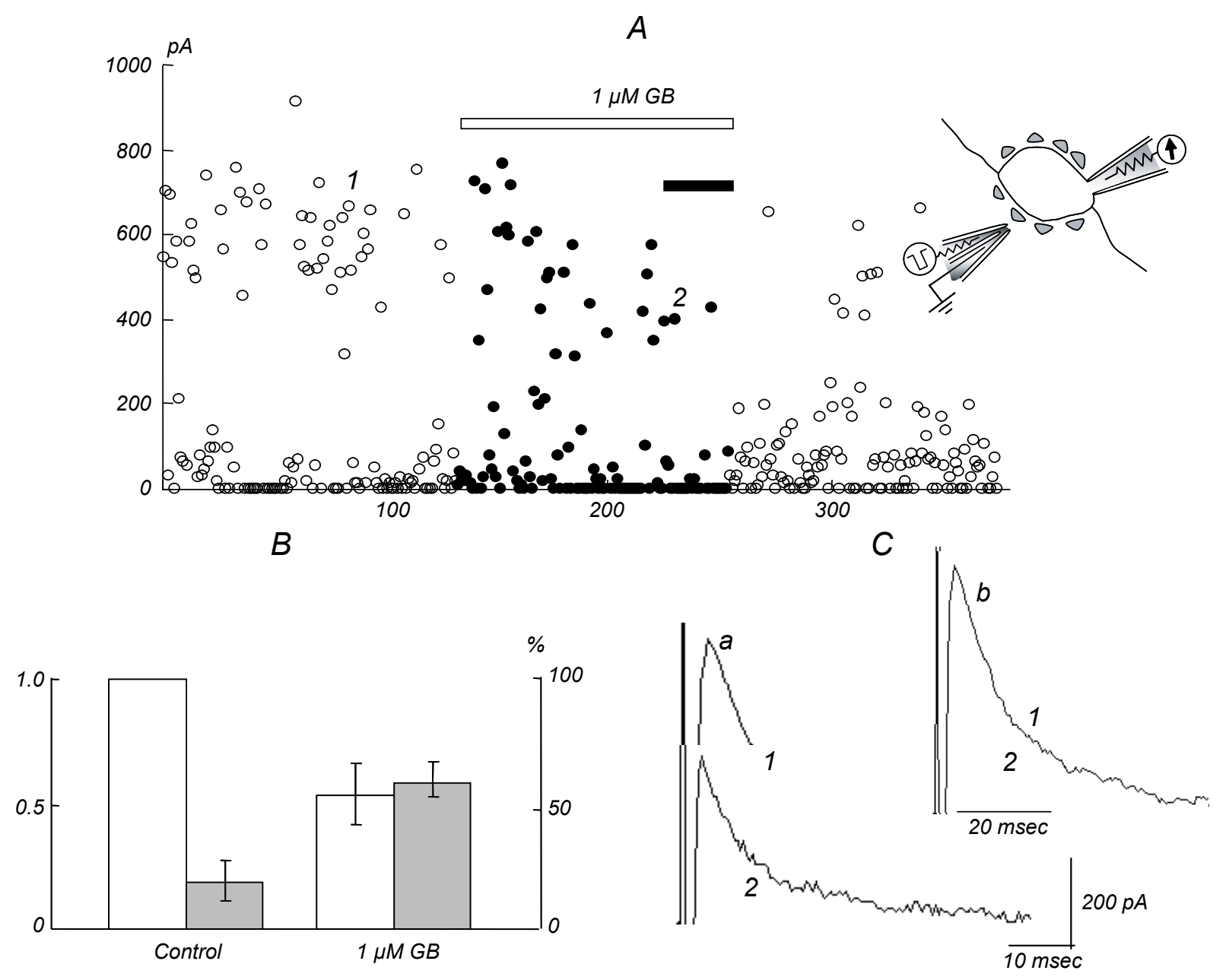

Fig. 3. The effect of ginkgolide $B(G B)$ on eIPSCs in a single glycinergic synapse.

A) Amplitudes of eIPSCs (pA) induced by repeated stimulation (abscissa, numbers of stimuli) and recorded before and during application of $1 \mu \mathrm{M} \mathrm{GB}$ and during the recovery. Focal stimulation was given every $5 \mathrm{sec}$. Analysis during GB application (filled circles) was made for $2 \mathrm{~min} 30 \mathrm{sec}$. Inset at the right is the same as in Fig.2A. B) Summarized results of the action $1 \mu$ M GB on the normalized eIPSC amplitude $(n=4, P<0.05)$ and $\left.\mathrm{R}_{\text {suc }}(\%, n=4, P<0.05) .{ }^{*} P<0.05 . \mathrm{C}\right)$ Original traces of eIPSCs with or without the action of $1 \mu \mathrm{M}$ GB. Currents normalized by the peak value are shown in the control (1) and after $1 \mu \mathrm{M}$ GB application (2).

Р и с. 3. Вплив гінкголіду Б на викликані гальмівні постсинаптичні струми в поодинокому гліцинергічному синапсі.

solutions, respectively. These results indicate that eIPSC is a $\mathrm{Cl}^{-}$current passing through glycine-gated chloride channels.

The effect of GB (1 and $10 \mu \mathrm{M})$ on eIPSCs elicited at every $5 \mathrm{sec}$ was examined by focal stimulation of a single glycinergic bouton. Application of $1 \mu \mathrm{M} \mathrm{GB}$ slightly decreased the eIPSC amplitude, as shown in Fig. 3A, B. At the same time, the $\mathrm{R}_{\text {suc }}$ for eIPSCs was also somewhat decreased. Gingkolide B applied in the concentration of $10 \mu \mathrm{M}$ significantly decreased both the eIPSC amplitude and $\mathrm{R}_{\text {suc }}$ (not illustrated). In addition, as is seen in Fig. $3 \mathrm{C}$, the inactivation kinetics of eIPSC was accelerated in the presence of
GB, indicating channel-blocker features for the GB effect.

\section{DISCUSSION}

Our data confirmed the inhibitory action of GB on glycine receptors previously reported for the active compound of Ginkgo biloba extract (GB) on glycine currents in spinal cord neurons. The details of the effect of the potent blocker GB on glycinergic transmission within the SDCN neuronal circuitry are reported at first. An additional new finding of this our 
study is the evidence for GB action as a modulator of the presynaptic glycine release machinery.

Recently, the potent antagonistic activity of ginkgolides with respect to inhibitory glycine-activated receptors was reported [24]. The analysis of receptordrug relationships for a wild type and selected point mutations of the channel-forming subunit of glycine receptors has revealed the use-dependent channel blocking potency for GB, as well as its selectivity to $\beta$ subunit-containing glycine receptors $[11,18]$. The latter point is indicative of the GB-induced blockade of postsynaptic glycine receptors. In the present study, we have combined the experiments on rat spinal cord slices and acutely isolated SDCN neurons to examine the efficacy of $\mathrm{GB}$ as a receptor blocker within the framework of synaptic, extrasynaptic, and mixed patterns of native glycine receptor-mediated transmission.

It is well documented that the inhibitory postsynaptic events in spinal cord slices are mediated by co-release of GABA and glycine within the same synaptic space and, in turn, by activation of both GABA and glycine receptors [19]. Glycinergic postsynaptic events were isolated, as described earlier [23]. The action of $1 \mu \mathrm{M}$ GB was examined on glycinergic sIPSCs recorded from neurons in slices and acutely isolated units. We found that $1 \mu \mathrm{M}$ GB influences sIPSCs in slices with a low efficacy but with an increased potency when used in the concentration of $10 \mu \mathrm{M}$.

With a purpose to further determine the effect of GB, we examined its action on glycine-elicited currents in freshly isolated SDCN neurons. An additional set of the experiments aimed to observe the effect of the examined drug on IPSCs evoked by focal stimulation of single synaptic boutons was performed. Postsynaptic currents evoked by focal single-bouton stimulations reflect the features of glycine receptor-mediated events, since they were insensitive to bicuculline and reversibly abolished by a competitive antagonist, strychnine $(1 \mu \mathrm{M})$. Moreover, the reversal potential for evoked postsynaptic currents was estimated as $-73.1 \mathrm{mV}$, which is rather close to the $E_{\mathrm{Cl}}$ calculated from Nernst equation for chloride ions $(-69 \mathrm{mV})$.

The kinetic features were compared for eIPSCs in the control and after GB pre-incubation $(10 \mu \mathrm{M})$. The half-decay time $\left(\tau_{1}\right)$ for control eIPSCs was calculated as $33 \mathrm{msec}$, whereas the half-decay time $\left(\tau_{2}\right)$ for eIPSCs in the presence of GB (10 min pre-perfusion) was significantly reduced and comprised $20 \mathrm{msec}$. Such acceleration of the current kinetics is indicative of the channel blocking action of GB, as was reported earlier [20]. In isolated neurons, $1 \mu \mathrm{M}$ GB did cause a slight decrease in the average eIPSC amplitude and $\mathrm{R}_{\text {suc }}$, while $10 \mu \mathrm{M}$ GB led to a significant reduction of the amplitude and $\mathrm{R}_{\text {suc }}$, suggesting that $\mathrm{GB}$ acts not only on post-synaptic glycine-gated $\mathrm{Cl}^{-}$channels but also on the pre-synaptic glycine release machinery, i.e., this agent reduces the release probability. The details of the presynaptic effect of GB remain uncertain and require further examination.

\section{К. Нонака ${ }^{1,2}$, О. Кондрацька ${ }^{1,4}$, М Маеда $^{1,3}$, Т. Ямага ${ }^{1}$, Н. мураяма ${ }^{2}$ М. Шін ${ }^{1}$, Н. Акайке}

\section{МОДУЛЯЦІЯ ГЛІЦИНЕРГІЧНОЇ ПЕРЕДАЧІ}

В НЕЙРОНАХ СПІНАЛЬНОГО ДОРСАЛЬНОГО КОМІСУРАЛЬНОГО ЯДРА ЩУРА ГІНКГОЛІДОМ В

\author{
${ }^{1}$ Університет наук про здоров'я, Кумамото (Японія). \\ ${ }^{2}$ Коледж наук та технологій при університеті Кумамото \\ (Японія). \\ ${ }^{3}$ Університет Куруме, Куруме (Японія). \\ ${ }^{4}$ Інститут фізіології ім. О. О. Богомольця НАН України, \\ Київ (Україна).
}

P е 3 ю м е

Вплив гінкголіду В (GB) - діючої сполуки екстракту з гінкго дволопатевого (Ginkgo biloba) на гліцинопосередковані синаптичні струми вивчався на нейронах спінального сакрального дорсального комісурального ядра (SDCN) щурів. Гальмівні постсинаптичні струми (ГПСС), викликані в препаратах зрізів спинного мозку, дозозалежно зменшувалися при аплікації GB. Амплітуда викликаних ГПСС під дією 10 мкM GB падала до $61 \pm 6.4 \% 3$ одночасним прискоренням кінетики струмів, що свідчило про наявність впливу на канальні пори. Як амплітуда, так і відносна кількість синаптичних подій (викликаних ГПСС), індукованих електричною фокальною стимуляцією поодиноких гліцинергічних нервових закінчень (бутонів), також зменшувались у присутності 1 мкM GB. Ці результати свідчать, що GB не тільки модулює постсинаптичні гліцинові рецептори, але й впливає на пресинаптичні механізми вивільнення гліцину.

\section{REFERENCES}

1. E. A. Barnard, "Receptor classes and the transmitter-gated ion channels," Trends Biochem. Sci., 17, 368-374 (1992).

2. H. Betz, J. Kuhse, V. Schmieden, et al., "Structure And functions of inhibitory and excitatory glycine receptors," Ann. New York Acad. Sci., 868, 667-676 (1999).

3. K. Morita, N. Motoyama, T. Kitayama, et al., "Spinal antiallodynia action of glycine transporter inhibitors in neuropathic pain models in mice," J. Pharmacol. Exp. Ther., 326, 633-645 (2008). 
4. H. U. Zeilhofer, "The glycinergic control of spinal pain processing," Cell Mol. Life Sci., 62, 2027-2035 (2005).

5. K. Hosl, H. Reinold, R. J. Harvey, et al., "Spinal prostaglandin E receptors of the Ep2 subtype and the glycine receptor alpha3 subunit, which mediate central inflammatory hyperalgesia, do not contribute to pain after peripheral nerve injury or formalin injection," Pain, 126, 46-53 (2006).

6. J. W. Lynch and R. J. Callister, "Glycine receptors: a new therapeutic target in pain pathways," Curr. Opin. Invest. Drugs, 7, 48-53 (2006).

7. S. M. Wojcik, S. Katsurabayashi, I. Guillemin, et al., "A shared vesicular carrier allows synaptic corelease of GABA and glycine," Neuron, 50, 575-587 (2006).

8. P. Legendre, "The glycinergic inhibitory synapse," Cell Mol. Life Sci., 58, 760-793 (2001).

9. H. Betz, B. Schmitt, C. M. Becker, et al., "Structure and biology of central nervous system neurotransmitter receptors," Biochem. Soc. Trans., 15, 107-108 (1987).

10. P. Braquet, "Proofs of involvement of PAF-acether in various immune disorders using BN 52021 (ginkgolide B): A powerful PAF-acether antagonist isolated from Ginkgo biloba L," Adv. Prostaglandin Thromboxane Leukot. Res., 16, 179-198 (1986).

11. E. L. Kondratskaya, H. Betz, O. A. Krishtal, and B. Laube, "The beta subunit increases the ginkgolide B sensitivity of inhibitory glycine receptors," Neuropharmacology, 49, 945951 (2005).

12. L. Ivic, T. T. Sands, N. Fishkin, K. Nakanishi, et al., "Terpene trilactones from Ginkgo biloba are antagonists of cortical glycine and GABA(A) receptors," J. Biol. Chem., 278, 4927949285 (2003)

13. S. Katsurabayashi, H. Kubota, H. Higashi, et al., "Distinct profiles of refilling of inhibitory neurotransmitters into presynaptic terminals projecting to spinal neurones in immature rats," J. Physiol., 560, 469-478 (2004).

14. L. J. Wu, Y. Li, and T. L. Xu, "Co-release and interaction of two inhibitory co-transmitters in rat sacral dorsal commissural neurons," NeuroReport, 13, 977-981 (2002).
15. J. Nabekura, T. L. Xu, J. S. Rhee, et al., “Alpha2-adrenoceptormediated enhancement of glycine response in rat sacral dorsal commissural neurons," Neuroscience, 89, 29-41 (1999).

16. E. D. Schomburg, E. Jankowska, and F. K. Wiklund, "Nociceptive input to spinal interneurones in reflex pathways from group I muscle afferents in cats," Neurosci. Res., 38, 447-450 (2000).

17. N. Akaike and A. J. Moorhouse, "Techniques: Applications of the nerve-bouton preparation in neuropharmacology," Trends Pharmacol. Sci., 24, 44-47 (2003).

18. N. Harata, J. Wu, H. Ishibashi, et al., "Run-down of the GABA response under experimental ischemia in acutely dissociated CA1 pyramidal neurons of the rat," J. Physiol, 500, Part 3, 673-688 (1997).

19. T. Shirasaki, K. Aibara, and N. Akaike, "Direct modulation of $\mathrm{GABA}_{\mathrm{A}}$ receptor by intracellular ATP in dissociated nucleus tractus solitarii neurons of rat," J. Physiol., 449, 551-572 (1992).

20. N. Akaike, N. Murakami, S. Katsurabayashi, et al., "Focal stimulation of single GABAergic presynaptic boutons on the rat hippocampal neuron," Neurosci. Res., 42, 187-195 (2002).

21. J. S. Rhee, Z. M. Wang, J. Nabekura, et al., "ATP facilitates spontaneous glycinergic IPSC frequency at dissociated rat dorsal horn interneuron synapses," J. Physiol., 524, Part 2, 471-483 (2000).

22. R. Hawthorne, B. A. Cromer, M. W. Parker, and J. W. Lynch, "Molecular determinants of ginkgolide binding in the glycine receptor pore," J. Neurochem., 98, 395-407 (2006).

23. I. S. Jang, H. J. Jeong, S. Katsurabayashi, and N. Akaike, "Functional roles of presynaptic GABA(A) receptors on glycinergic nerve terminals in the rat spinal cord," J. Physiol., 541, 423-434 (2002).

24. E. L. Kondratskaya, P. V. Lishko, S. S. Chatterjee, and O. A. Krishtal, "BN52021, a platelet activating factor antagonist, is a selective blocker of glycine-gated chloride channel," Neurochem. Int., 40, 647-653 (2002).

25. K. Murase, M. Randic, T. Shirasaki, et al., "Serotonin suppresses $\mathrm{N}$-methyl-D-aspartate responses in acutely isolated spinal dorsal horn neurons of the rat," Brain Res., 525, 84-91 (1990). 